\title{
STRATEGI PENGEMBANGAN SCIENCE GENERIC SKILLS (SGS) CALON GURU FISIKA MELALUI MODEL PEMBELAJARAN GROUP INVESTIGATION PADA MATA KULIAH PRAKTIKUM
}

\author{
Andi Fadllan
}

\begin{abstract}
Abstrak
Beberapa hasil penelitian menunjukkan masih rendahnya keterampilan generik lulusan perguruan tinggi, seperti keterampilan berkomunikasi, bekerjasama, motivasi, inisiatif, kreativitas, dan kemampuan berpikir logis, sistematis dan komprehensif. Kondisi ini ternyata juga terjadi di LPTK yang notabene sebagai produsen guru.

Dalam tulisan ini akan dipaparkan bagaimana strategi pengembangan Science Generic Skills mahasiswa melalui Model Pembelajaran Group Investigation pada mata kuliah praktikum.

Sebagai sebuah model pembelajaran kooperatif, penerapan Group Investigation pada mata kuliah praktikum dapat menjadi alternatif dalam mengembangkan Keterampilan Generik Sains calon guru. Adapun strategi penerapannya dapat dilakukan dengan melibatkan mahasiswa sejak perencanaan, pelaksanaan, hingga evaluasi praktikum melalui tahap-tahap dalam model Group Investigation, yang meliputi: 1) mengidentifikasi topik dan membagi siswa ke dalam kelompok, 2) merencanakan tugas, 3) membuat penyelidikan, 4) mempersiapkan tugas akhir (analisis dan sintesis), 5) mempresentasikan tugas akhir, dan 6) evaluasi.
\end{abstract}

Kata kunci: Science Generic Skills (SGS), Group Investigation 


\section{A. Pendahuluan}

Pembelajaran di perguruan tinggi diakui atau tidak masih menyisakan problem mendasar yang perlu mendapat perhatian, yakni tidak berjalannya proses pembentukan karakter dan pengembangan keterampilan kerja mahasiswa. Pembelajaran yang dilaksanakan oleh dosen lebih mengedepankan transfer of knowledge daripada penyiapan mahasiswa menghadapi dunia kerja. Berdasarkan hasil survei NACE pada tahun 2002 terhadap 457 pemimpin perusahaan tentang kualitas terpenting pada diri seseorang, diperoleh hasil berturut-turut adalah kemampuan berkomunikasi, kejujuran dan integritas, kemampuan bekerjasama, kemampuan interpersonal, beretika, motivasi dan inisiatif, kemampuan beradaptasi, daya analitis, kemampuan komputer, kemampuan berorganisasi, berorientasi pada detil, kepemimpinan, kepercayaan diri, ramah, sopan, bijaksana, IPK, kreatif, humoris, dan kemampuan berwirausaha (Irma, 2007). Hasil survei tersebut menunjukkan bahwa IPK hanya menduduki urutan ke17 pada indikator dan kemampuan yang mencerminkan kualitas seseorang. Sementara faktor-faktor yang lain, misalnya kemampuan berkomunikasi, kejujuran dan integritas, kemampuan bekerjasama, daya analitis, kepemimpinan, dan lain-lain justru memegang peranan penting dalam keberhasilan seseorang di tempat kerja.

Kondisi tersebut sebenarnya terjadi banyak di perguruan tinggi di Indonesia, tak terkecuali di Lembaga Perguruan Tinggi Kependidikan (LPTK) yang notabene merupakan produsen calon guru. Lulusan yang dihasilkan selama ini belum menunjukkan keterampilan seperti yang diharapkan. Misalnya, kemampuan mahasiswa calon guru masih rendah padahal kemampuan merupakan faktor utama dalam mengelola pembelajaran. Begitupun dengan motivasi, inisitaif, kreativitas dan karakter-karakter lainnya. Padahal jika menilik pada kompetensi seorang guru profesional, maka LPTK sudah seharusnya menyiapkan mahasiswanya agar memiliki kompetensi tersebut yang meliputi kompetensi profesional, kompetensi pedagogik, kompetensi sosial, dan kompetensi kepribadian. 
Berangkat dari kondisi dan problem seperti itu, maka perlu adanya strategi untuk mengembangkan keterampilan generik pada mahasiswa, khususnya pada mahasiswa sains yang berupa Science Generic Skills (SGS) atau Keterampilan Generik Sains. Pengembangan Science Generic Skills sendiri dapat terintegrasi dalam setiap pembelajaran baik pada mata kuliah yang bersifat teoritis maupun praktis.

Mata kuliah praktikum merupakan mata kuliah yang mendukung pemahaman mahasiswa terhadap teori dan konsep-konsep yang diperoleh pada mata kuliah yang bersifat teoritis. Karenanya, desain perkuliahan praktikum tidak hanya memberikan penekanan pada aspek teoritis tetapi juga pada aspek praktis. Kondisi ini mensyaratkan adanya laboratorium yang dilengkapi dengan peralatan untuk melakukan percobaan atau eksperimen.

Dalam melakukan percobaan atau eksperimen, mahasiswa tidak hanya dilatih dalam menyusun/merangkai dan menggunakan serta memanipulasi alat, tetapi lebih dari itu, mahasiswa dilatih untuk mengembangkan generic skills (keterampilan dasar), utamanya pada Science Generic Skills (SGS) atau Keterampilan Generik Sains. Keterampilan Generik Sains (KGS) merupakan keterampilan dasar yang mutlak dimiliki oleh setiap mahasiswa calon guru fisika. Keterampilan inilah yang nantinya akan bermanfaat bagi mahasiswa baik ketika menempuh perkuliahan maupun saat terjun di dunia kerja kelak, utamanya ketika menghadapi permasalahan yang harus dipecahkan secara cepat, tepat, dan sistematis.

Keterampilan Generik Sains (KGS) memiliki peran yang sangat penting dalam meningkatkan pemahaman mahasiswa terhadap teori dan konsep-konsep fisika yang ada serta mendukung pembelajaran dengan memberikan penekanan pada proses dan produk sains. Hal ini sejalan dengan tujuan pembelajaran fisika yaitu meningkatkan kemampuan berpikir mahasiswa secara sistematis, objektif, dan kreatif dalam segala hal dan memiliki keterampilan dalam aspek psikomotorik. Untuk memberikan penekanan pada keterampilan proses, maka mahasiswa dilatih untuk merencanakan, memprediksi, menghitung, mengukur, 
mengklasifikasi, mengamati, menyimpukan, dan mengomunikasikan dalam kegiatan eksperimen.

Down dan Hill dalam Mubarak (2009) menyatakan bahwa tujuan generic skills adalah agar pengetahuan dan kecakapan yang diperoleh dari hasil belajar akan dapat diaplikasikan pada bidang kehidupan sosial, teknologi, atau pada setiap perubahan konteks, namun yang lebih utama adalah menghasilkan efisiensi yang lebih besar melalui pengetahuan yang lebih efektif dan penggunaan kecakapan.

Keterampilan Generik Sains mahasiswa selama ini cenderung dan sering kurang mendapatkan perhatian bahkan terabaikan. Misalnya, keterampilan dalam membuat grafik dan menganalisisnya. Mahasiswa sering mengalami kesulitan bagaimana menentukan masing-masing sumbu grafik sesuai variabel atau besaran yang diinginkan, meletakkan titik-titk data jika grafik dalam tiga dimensi, dan memberikan garis utama pada sebaran data. Selain itu, dalam menuliskan simbol matematik, mahasiswa juga mengalami kesulitan untuk menentukan kapan penggunaan simbol-simbol matematika sesuai peruntukannya. Bahkan, dalam menuliskan satuan dari besaran yang terukur, mahasiswa sering mengabaikannya sehingga nilai yang terukur tidak memiliki makna fisis. Yang lebih memprihatinkan, mahasiswa tidak peduli dengan penggunaan angka penting dan notasi ilmiah. Pengabaian terhadap angka penting dan notasi ilmiah akan berdampak pada validitas dan tingkat keakuratan data yang diperoleh.

Dalam tulisan ini akan dipaparkan bagaimana strategi pengembangan Science Generic Skills mahasiswa melalui Model Pembelajaran Group Investigation pada mata kuliah praktikum.

\section{B. Science Generic Skills (Keterampilan Generik Sains)}

Laboratorium merupakan suatu tempat atau ruangan yang dilengkapi dengan peralatan tertentu untuk melakukan suatu percobaan atau penyelidikan. ${ }^{1}$ Laboratorium berperan sangat

1 Margono, H. 2000. Metode Laboratorium. Malang: Jurusan Pendidikan Biologi FMIPA Universitas Negeri Malang Press

Jurnal PHENOMENON, Volume 1 Nomor 1, Juli 2011 
penting dalam mendukung pembelajaran fisika baik di sekolah dasar dan menengah maupun di perguruan tinggi. Beberapa peran penting laboratorium di antaranya, pertama, sebagai wahana untuk mengembangkan keterampilan dasar (Keterampilan Generik Sains) atau keterampilan proses sains (science process skills), seperti mengamati, mengukur, mencatat, membuat tabel, menganalisis data, menarik kesimpulan, dan berkomunikasi. Kedua, laboratorium sebagai wahana untuk membuktikan konsep atau hukum-hukum alam (verification experiment) sehingga dapat memperjelas konsep yang telah dibahas sebelumnya. Melalui kegiatan di laboratorium, mahasiswa dapat menemukan antara konsep secara teoritis dan bukti fisis secara otentik. Ketiga, sebagai wahana mengembangkan keterampilan berpikir melalui proses pemecahan masalah untuk menemukan konsep sendiri (inquiry experiment). Dalam proses penemuan sendiri tersebut, mahasiswa secara aktif terlibat dalam upaya pencarian mendalam dengan menggunakan daya hipotesis dan analisisnya untuk memecahkan masalah yang ditemuinya. Melalui ketiga peran ini, laboratorium telah menjadi wahana learning how to learn. ${ }^{2}$ Laboratorium tidak lagi hanya sebagai pemanis, di mana hanya menjadi syarat formal dalam proses pembelajaran fisika.

Menurut Brotosiswoyo dalam Taufiq dan Wiyono (2009), Keterampilan Generik Sains yang diperoleh dari proses pembelajaran dimulai dengan: (1) pengamatan tentang gejala alam, (2) kesadaran akan skala besaran (sense of scale), (3) bahasa simbolik, (4) kerangka logika taat asas (logical self-consistency), (5) inferensi logika, (6) hukum sebab akibat (causality), (7) pemodelan matematik, dan (8) membangun konsep. Proses pengamatan merupakan modal utama dan pertama dalam melaksanakan eksperimen. Melalui pengamatan, mahasiswa akan diajak untuk menemukan fenomena-fenomena dan gejala fisika sehingga akan muncul rasa ingin tahu terhadap fenomena atau gejala tersebut. Pengamatan ini dapat dilakukan baik secara langsung menggunakan panca indera ataupun tidak langsung, artinya membu-

2 Gunawan, et. al. 2009. Developing Virtual Laboratory for Teaching Modern Physics. Proceeding International Seminar on Science Education. 
tuhkan bantuan alat sesuai karateristik fenomena yang diamati. Karenanya, tentu bukan tanpa alasan ayat al qur'an pertama kali diturunkan adalah surat Al Alaq: 1-5 yang memerintahkan kepada Muhammad SAW untuk membaca. Tidak hanya membaca dalam arti yang sempit, tetapi membaca dalam arti yang lebih luas, yakni melakukan pengamtan terhadap alam dan isinya.

\section{Pengembangan Science Generic Skills Melalui Model Pem- belajaran Group Investigation}

Berdasarkan hasil penelitian yang dilakukan oleh Rusnayati dan Samsudin terhadap mahasiswa di salah satu LPTK di Jawa Barat, didapatkan kenyataan bahwa Keterampilan Generik Sains mahasiswa khususnya dalam membuat grafik secara manual masih rendah. Hasil pembuatan grafik secara manual oleh mahasiswa memiliki tingkat ketelitian yang lebih rendah dibandingkan dengan pembuatan grafik menggunakan software Origin 5 atau Microsoft Excell. Kesalahan yang sering muncul dalam pembuatan grafik adalah mahasiswa lebih mementingkan banyaknya titik yang terlewati dibandingkan simpangan baku dari data tersebut. Selain itu, saat membuat batas ujung antara garis utama dan garis bayangan, mahasiswa tidak menggambarkan batas secara ujung tegak lurus dengan sumbu X-nya melainkan tegak lurus dengan antargarisnya.

Hasil penelitian tersebut menunjukkan kesalahan mendasar yang sering terjadi pada mahasiswa calon guru fisika. Jika hal ini terus-menerus dilakukan dan tidak terpantau dengan baik oleh dosen maupun asisten praktikum, maka akan berakibat pada rendahnya Keterampilan Generik Sains mahasiswa itu sendiri. Oleh karenanya, diperlukan langkah-langkah nyata dan sistematis untuk mengembangkan Keterampilan Generik Sains mahasiswa melalui proses pembelajaran khususnya pada mata kuliah jenis praktikum.

Dalam mengembangkan Keterampilan Generik Sains mahasiswa melalui kegiatan praktikum, dosen pengampu mata kuliah praktikum terlebih dahulu memberikan ulasan singkat tentang mekanisme pelaksanaan kegiatan praktikum, mulai dari 
perencanaan, pelaksanaan hingga pelaporan. Pada mata kuliah praktikum untuk mahasiswa tingkat dasar, perencanaan praktikum biasanya dilakukan sendiri oleh dosen bersama asisten dosen sehingga tidak ada keterlibatan mahasiswa. Sedangkan dalam pelaporan, mahasiswa diminta untuk menyusun laporan tertulis secara individu.

Meskipun langkah-langkah pelaksanaan kegiatan praktikum hampir sama di semua perguruan tinggi, namun jika menilik pada hasil penelitian di atas, tentu perlu dilakukan upaya yang lebih keras untuk meningkatkan Keterampilan Generik Sains mahasiswa. Salah satunya dengan melibatkan mahasiswa dalam perencanaan kegiatan praktikum dan membudayakan diskusi di setiap awal dan akhir praktikum. Dengan saling berdiskusi, diharapkan mahasiswa dapat saling bertukar pikiran tentang laporan yang telah disusun khususnya pada aspekaspek Keterampilan Generik Sains, seperti menuliskan simbol matematika dan satuan, kesadaran terhadap skala besaran, melakukan pengukuran dengan tepat, menggambar dan menganalisis grafik, membuat tabel, serta menghubungkan antara temuan eksperimen dengan penjelasan secara teoritis.

Untuk mendukung upaya tersebut, salah satu model pembelajaran kooperatif yang dapat diterapkan adalah model Group Investigation atau Penyelidikan Kelompok.

Group Investigation merupakan salah satu bentuk model pembelajaran kooperatif yang menekankan pada partisipasi aktif peserta didik untuk mencari sendiri materi (informasi) yang akan dipelajari melalui bahan-bahan yang tersedia, baik dari buku teks, hand-out, modul, atau sumber-sumber lain seperti majalah, jurnal ilmiah, dan internet. Model pembelajaran ini tepat digunakan untuk pembelajaran di perguruan tinggi karena menekankan pada keterampilan berpikir tingkat tinggi (high order thinking skill) mahasiswa. Dalam pelaksanaannya, mahasiswa dilibatkan secara total baik dalam merencanakan kegiatan pembelajaran, menentukan topik maupun cara untuk mempelajarinya melalui investigasi. Model pembelajaran ini menuntut mahasiswa untuk memiliki kemampuan yang baik dalam 
berkomunikasi maupun dalam keterampilan-keterampilan proses lainnya. Model Group Investigation dapat melatih mahasiswa untuk menumbuhkan kemampuan berfikir secara mandiri. Keterlibatan mahasiswa secara aktif dapat terlihat mulai dari tahap pertama sampai tahap akhir pembelajaran.

Model pembelajaran Group Investigation terdiri atas tiga konsep utama, yaitu: 1) penelitian atau inquiri, 2) pengetahuan atau knowledge, dan 3) dinamika kelompok atau the dynamic of the learning group (Udin S. Winaputra, 2001:75). Penelitian adalah proses dinamika mahasiswa dalam memberikan respon terhadap masalah yang ada dan upaya untuk memecahkannya melalui proses yang disusun sendiri oleh mahasiswa. Konsep pertama ini mutlak ada karena di sinilah letak kekuatan dari model ini, di mana mahasiswa dilatih untuk mengembangkan kemampuan berpikir kritis, kreatif dan inovatif sekaligus meningkatkan kemampuan berkomunikasi dan bekerjasama dalam kelompok. Sementara itu, pengetahuan adalah pengalaman belajar yang diperoleh mahasiswa baik secara langsung maupun tidak langsung. Pengalaman secara langsung diperoleh mahasiswa melalui proses pencarian yang dilakukannya baik melalui kegiatan observasi, diskusi, maupun eksperimen, sedangkan pengalaman tidak langsung diperoleh melalui dokumentasi atau studi literatur. Dinamika kelompok menunjukkan suasana yang menggambarkan interaksi antarmahasiswa yang melibatkan berbagai ide dan pendapat serta saling bertukar pengalaman melalui proses saling beragumentasi.

Untuk dapat mengembangkan Keterampilan Generik Sains mahasiswa, Slavin (1995) dalam Siti Maesaroh (2005:28), mengemukakan hal penting untuk melakukan model Group Investigation:

1. Membutuhkan Kemampuan Kelompok.

Dalam menerapkan model Group Investigation ini, dosen hendaknya membuat desain pembelajaran yang memungkinkan setiap mahasiswa memberikan kontribusinya dalam kerja kelompok, misalnya melalui kegiatan observasi, setiap kelompok diminta mengatur tugas anggota kelompoknya masing-masing. 
Dalam kegiatan penyelidikan ini, mahasiswa dapat memperkaya informasi melalui bahan ajar yang tersedia. Kemudian informasi yang diperoleh dijadikan sebagai dasar dalam mengerjakan tugas yang diberikan.

2. Rencana Kooperatif.

Dalam menumbuhkan kemampuan kerja kelompok, mahasiswa secara bersama-sama menyelidiki tentang masalah yang akan mereka pelajari, bagaimana cara mempelajarinya, sumber apa saja yang dibutuhkan, siapa melakukan apa, dan bagaimana mereka akan mempresentasikan hasil kerja mereka di dalam kelas.

\section{Peran Guru.}

Dalam model pembelajaran Group Investigation, dosen tidak hanya berperan sebagai salah satu sumber belajar bagi mahasiswa tetapi juga lebih berperan sebagai fasilitator. Untuk dapat memfasilitasi kebutuhan di tiap-tiap kelompok, maka dosen perlu mengatur mobilitasnya dalam interaksi dengan mahasiswa atau membantu interaksi antarmahasiswa. Bahkan, jika memang diperlukan, dosen dapat terlibat dalam interaksi kelompok untuk membantu mahasiswa.

Sebagai salah satu tipe model pembelajaran kooperatif, Group Investigation menekankan adanya kerja kelompok. Karenanya, dapat dipastikan bahwa kelas yang menerapkan model pembelajaran ini akan membagi mahasiswa menjadi kelompokkelompok kecil. Umumnya kelas dibagi menjadi beberapa kelompok yang beranggotakan 5 sampai 6 orang dengan karakteristik yang heterogen, (Trianto, 2007:59). Pembagian kelompok dapat dilakukan atas beberapa pertimbangan selain hetergonitas, misalnya atas dasar kesamaan minat terhadap topik tertentu.

Karena sifatnya yang mendorong kerjasama antarmahasiswa dalam kelompok, maka model Group Investigation dapat diterapkan pada mata kuliah praktikum. Model ini dapat menjadi alternatif bagi mahasiswa untuk melakukan praktikum pada topik-topik tertentu yang mereka ingin pelajari, sehingga mereka akan tumbuh rasa tanggung jawab terhadap pilihannya 
dan tidak setengah hati melakukan kegiatan praktikum karena topik yang dipelajari sudah tidak menarik lagi.

Pengembangan Keterampilan Generik Sains mahasiswa melalui Group Investigation dapat dilakukan melalui langkahlangkah sebagai berikut:

\section{Identifikasi topik}

Mahasiswa diminta memilih berbagai subtopik yang akan dipelajari dalam mata kuliah tertentu. Misalnya dalam mata kuliah Praktikum Fisika Dasar untuk Program Studi Pendidikan Fisika, mahasiswa memilih satu dari topik-topik berikut: kinematika dan dinamika gerak, fluida, energi dan gelombang, optika, kelistrikan dan kemagnetan. Kemudian, mahasiswa dibagi menjadi kelompok-kelompok yang berorientasi pada tugas (task oriented groups) yang beranggotakan 2 hingga 6 orang. Mereka diminta untuk mempelajari topik yang sudah dipilih tersebut dan mencari penjelasannya melalui praktikum yang disusun dengan cara mereka sendiri. Hal ini memungkinkan tiap kelompok melakukan praktikum yang berbeda meski dengan topik yang sama, misalnya pada topik tentang gerak harmonik sederhana, ada kelompok yang menggunakan ayunan sederhana dan ada kelompok yang menggunakan pegas yang diberi beban. Adapun komposisi kelompok diupayakan heterogen baik dalam jenis kelamin, etnik maupun kemampuan akademik.

\section{Perencanaan tugas}

Mahasiswa difasilitasi dosen merencanakan berbagai prosedur belajar khusus, tugas dan tujuan umum yang konsisten dengan berbagai topik dan subtopik yang telah dipilih dari langkah sebelumnya. Tiap-tiap kelompok mendesain kegiatan praktikum yang nantinya akan diperoleh rancangan kegiatan praktikum.

\section{Implementasi}

Pada tahap ini mahasiswa melaksanakan rencana yang telah disusun pada langkah kedua. Sebagai contoh, kelompok yang telah memilih topik tentang gerak harmonik sederhana

Jurnal PHENOMENON, Volume 1 Nomor 1, Juli 2011 
menggunakan pegas kemudian menyiapkan pegas, beban, statif dan neraca pegas. Alat-alat ini kemudian dirangkai sendiri oleh mahasiswa untuk memperoleh data yang diinginkan, misalnya data tentang percepatan gravitasi di dalam kelas.

Dalam kegiatan praktikum, dosen melakukan pengamatan terhadap aktivitas mahasiswa utamanya pada keteramplan generik sains yang muncul. Keterampilan-keterampilan yang dapat diobservasi oleh dosen meliputi: keterampilan menyiapkan alat dan bahan yang dibutuhkan, menyusun hipotesis, menyusun dan merangkai alat dan bahan sesuai tujuan praktikum, melakukan pengukuran atau pengambilan data, menuliskan hasil pengukuran atau data yang diperoleh.

\section{Analisis dan sintesis}

Pada tahap ini mahasiswa menganalisis dan mensintesis berbagai informasi yang diperoleh melalui praktikum. Jika informasi yang diperoleh dalam bentuk angka atau nilai, maka perlu dianalisis secara statistik. Sedangkan jika informasi berupa data kualitatif, maka perlu dianalisis menggunakan teori yang ada. Hasil dari analisis dan sintesis yang ini kemudian menjadi bahan presentasi yang disajikan di akhir kegiatan. Melalui kegiatan ini mahasiswa diajak untuk berpikir secara logis, sistematis, dan komprehensif.

\section{Penyajian hasil akhir}

Setiap kelompok menyajikan hasil kerja kelompoknya dalam bentuk presentasi dari berbagai topik yang telah dipelajari. Tujuannya agar seluruh mahasiswa dapat mengetahui sejauhmana hasil kerja kelompok lain. Dengan saling melihat dan memberikan pendapat serta argumentasi, mahasiswa akan dilatih untuk bertanggung jawab, menumbuhkan rasa percaya diri, saling menghargai dan berkomunikasi.

\section{Evaluasi}

Dosen bersama mahasiswa melakukan evaluasi terhadap kontribusi yang diberikan oleh tiap-tiap kelompok terhadap pe- 
kerjaan kelas sebagai suatu keseluruhan. Evaluasi dapat mencakup tiap mahasiswa secara individu maupun kelompok, atau keduanya.

Tahapan-tahapan kemajuan dalam pembelajaran yang menggunakan model Group Investigation dapat dijabarkan seperti pada pada tabel berikut, (Slavin, 1995) dalam Siti Maesaroh (2005:29-30):

Enam Tahapan Kemajuan dalam Pembelajaran Kooperatif dengan Model Group Investigation

\begin{tabular}{|c|c|}
\hline $\begin{array}{c}\text { Tahap I } \\
\text { Mengidentifikasi topik } \\
\text { dan membagi siswa ke } \\
\text { dalam kelompok. }\end{array}$ & $\begin{array}{l}\text { Dosen memberikan kesempatan } \\
\text { bagi mahasiswa untuk memberikan } \\
\text { kontribusi terhadap apa yang akan } \\
\text { mereka selidiki. Kelompok dibentuk } \\
\text { berdasarkan heterogenitas. }\end{array}$ \\
\hline $\begin{array}{c}\text { Tahap II } \\
\text { Merencanakan tugas. }\end{array}$ & $\begin{array}{l}\text { Kelompok akan membagi sub topik } \\
\text { kepada seluruh anggota. Kemudian } \\
\text { membuat perencanaan dari masalah } \\
\text { yang akan diteliti, bagaimana proses } \\
\text { dan sumber apa yang akan dipakai. }\end{array}$ \\
\hline $\begin{array}{c}\text { Tahap III } \\
\text { Membuat penyelidikan. }\end{array}$ & $\begin{array}{l}\text { Kelompok mengumpulkan, menga- } \\
\text { nalisis dan mengevaluasi informasi, } \\
\text { membuat kesimpulan dan menga- } \\
\text { plikasikan bagian mereka ke dalam } \\
\text { pengetahuan baru dalam mencapai } \\
\text { solusi masalah kelompok. }\end{array}$ \\
\hline $\begin{array}{c}\text { Tahap IV } \\
\text { Mempersiapkan tugas } \\
\text { akhir. }\end{array}$ & $\begin{array}{l}\text { Setiap kelompok mempersiapkan } \\
\text { tugas akhir yang akan dipresentasi- } \\
\text { kan di depan kelas. }\end{array}$ \\
\hline $\begin{array}{c}\text { Tahap V } \\
\text { Mempresentasikan } \\
\text { tugas akhir. }\end{array}$ & $\begin{array}{l}\text { Kelompok mempresentasikan ha- } \\
\text { sil kerjanya. Kelompok lain tetap } \\
\text { mengikuti. }\end{array}$ \\
\hline $\begin{array}{l}\text { Tahap VI } \\
\text { Evaluasi. }\end{array}$ & $\begin{array}{l}\text { Soal ulangan mencakup seluruh } \\
\text { topik yang telah diselidiki dan di- } \\
\text { presentasikan. }\end{array}$ \\
\hline
\end{tabular}


Dari tahapan kemajuan di atas dan contoh penerapannya dalam mata kuliah praktikum, maka model Group Investigation ini dapat menjadi alternatif dalam mengembangkan Keterampilan Generik Mahasiswa calon guru. Melalui model pembelajaran ini, mahasiswa dilatih untuk tidak hanya menerima informasi tetapi juga mencari informasi/pengetahuan. Di samping itu, mahasiswa juga dilatih untuk mengembangkan keterampilan generiknya untuk mendukung penguatan kompetensinya sebagai calon guru, baik keterampilan berpikir tingkat tinggi, berpikir logis, sistematis, dan komprehensif, maupun keterampilan dalam berkomunikasi untuk menyampaikan ide dan gagasannya.

\section{Simpulan}

Dari uraian di atas dapat disimpulkan bahwa penerapan model pembelajaran kooperatif Group Investigation pada mata kuliah praktikum dapat menjadi alternatif dalam mengembangkan Keterampilan Generik Sains calon guru. Adapun strategi penerapannya dapat dilakukan dengan melibatkan mahasiswa sejak perencanaan, pelaksanaan, hingga evaluasi praktikum melalui tahap-tahap dalam model Group Investigation, yang meliputi: 1) mengidentifikasi topik dan membagi siswa ke dalam kelompok, 2) merencanakan tugas, 3) membuat penyelidikan, 4) mempersiapkan tugas akhir (analisis dan sintesis), 5) mempresentasikan tugas akhir, dan 6) evaluasi.[] 


\section{DAFTAR PUSTAKA}

Fadllan, Andi. 2006. Panduan Praktikum Fisika Dasar I. Semarang: Fakultas Tarbiyah IAIN Walisongo.

Fadllan, Andi. 2006. Panduan Praktikum Fisika Dasar II. Semarang: Fakultas Tarbiyah IAIN Walisongo.

Irma, Dewi. 2007. Soft Skill?. Pikiran Rakyat, Kamis 17 Juni 2007. Tersedia: http:/ / aargantenk.multiply.com/journal/item /70/Soft_Skill.

Margono, H. 2000. Metode Laboratorium. Malang: Jurusan Pendidikan Biologi FMIPA Universitas Negeri Malang.

Rusnayati, H. dan Samsudin, A. 2010. Kegiatan Eksperimen Fisika Dasar I untuk Mengembangkan Generic Skills Calon Guru Fisika. Semarang: Prosiding Seminar Nasional Fisika 2010 Jurusan Fisika UNNES.

Semiawan, C. 1992. Pendekatan Keterampilan Proses. Jakarta: Gramedia Widiasarana Indonesia.

Subhan, M., Hendratto, S., dan Wiyanto. 2010. Pengembangan Activity-Based Assessment untuk Mengukur Keterampilan Proses Eksperimen Fisika pada Siswa SMP 3 Bawen Kabupaten Semarang. Semarang: Prosiding Seminar Nasional Fisika 2010 Jurusan Fisika UNNES.

Taufiq and Wiyono, K. 2009. The Application of Hypothetical Deductive Learning Cycle Model to Improve Senior High School Students' Science Generic Skills on Rigid Body Equilibrium. Proceeding International Seminar on Science, p. 641-648. 